\title{
Gender Representation and Language Politeness in Speech Events of Senior High School Students and Vocational High School Student in Samarinda: A Pragmatic Study
}

\author{
Hanik Wahyu Ningsih \\ Magister Program of Language, Art and \\ Literature Education of Indonesia \\ Mulawarman University \\ Samarinda, Indonesia \\ Hani@smkti.net
}

\author{
Widyatmike Gede Mulawarman \\ Magister Program of Language, Art and \\ Literature Education of Indonesia \\ Mulawarman University \\ Samarinda, Indonesia \\ widyatmikegedemulawarman@yahoo.co.id
}

\author{
Mursalim \\ Magister Program of Language, Art and \\ Literature Education of Indonesia \\ Mulawarman University Samarinda, \\ Indonesia \\ Mursalim.unmul@yahoo.com
}

\begin{abstract}
Language politeness is categorized into two levels different. The first level refers to ethics or principles of behavioural appropriateness in society. On the other hand, the second level refers to the use of language to maintain interpersonal relationships. This study aims to describe the gender representation and politeness of language in the speech events of high school and vocational students in Samarinda City. The method used in this research is descriptive qualitative. Data collection techniques used through observation, recording, and card record. Determination of compliance and deviation from the principle of language politeness is based on indicators of language courtesy derived from Leech's theory. Data analysis techniques in this study were transcription of data from recordings; identifying, classifying, and clarifying data; copy to data card; analyzing data cards; and draw conclusions. The results showed that female students obeyed the principle of politeness in language for female teachers than male teachers and several times made deviations for male teachers than female teachers. Whereas male students obey the principle of politeness for female teachers rather than male teachers and several times commit irregularities in male teachers than female teachers. Compliance with the principle of politeness in female students is found in (1) maxim of acceptance (2) maxim of humility (3) maxim of agreement (4) and maxim of sympathy. Compliance with the principle of politeness in male students is found in (1) the maxim of wisdom, (2) the maxim of humility, (3) the maxim of sympathy.
\end{abstract}

Keywords: gender representation, politeness in language, speech events

\section{INTRODUCTION}

The politeness of language is related to the relationship between two participants which can be referred to as 'oneself' and 'others [5]'. The principle of politeness has several maxims, namely tact maxim (tact maxim), generosity maxim (generosity maxim), the maxim of acceptance (approbation maxim), the modesty maxim (modesty maxim), the maxim of compatibility (agreement maxim), and the sympathy maxim (sympathy maxim). The principle of politeness is related to two conversation participants, namely oneself (self) and others (other). The self is the speaker and the other person is the opposite of the speaker [7]

The politeness of language is an important part of communication. As in the conversation of students with teachers and students with students during teaching and learning activities in class can be said as a speech event. The communication process produces utterances that are very varied. Varied utterances in teaching and learning activities is due to several factors [6]. Chaer and Agustina suggested that variation is diversity or difference in language usage. Variation can occur if language speakers are not homogeneous. In addition, variations can also occur due to the diversity of social interaction activities of language speakers. The determinants of language variation include time, place, sociocultural, situation and medium disclosure factors [1].

Based on preliminary observations of the speech of students, both men and women show that the difference in language response is more to the content or content of the conversation, not too much-nonsense or even without further ado. Male students prefer to communicate directly on the subject and emphasize the content and purpose of the conversation. While female students are concerned with how they speak and how they convey their message. Participants in speech often use indirect speech as a strategy for speaking, for example, participants in speech use lip service to control politeness. Similarly, the speech of male and female students in SMA and SMK Samarinda city. In connection with this background, the focus of research on the politeness of the language of male and female students during learning, because in its use there are differences in the ways and language responses between men and women.

Some relevant research on politeness in language based on gender has been done, including by Febriadina 


\section{RESULTS AND DISCUSSION}

conducting research with the politeness of male and female students in Sragen, Central Java. Researchers conducted research in the field of sociopragmatics in the form of student speech. Vocational high school student research subjects with the object of students' politeness research. The results found different forms of politeness in language between male and female students [4].

In addition, Dwipayana conducted a study entitled the politeness of speech in the choice of student language codes in the SMAN 1 Ubud community in terms of Gender Perspectives: A Socioprgamatic Study. The results showed positive and negative politeness in the speech of male and female students at SMA 1 Ubud [3].

The similarity between the two studies with this research is that they both examine the principle of politeness in the form of language and deviations from students' maxims towards teachers based on a gender perspective. While the difference between the two studies with this research is located in the research subject which combines high school and vocational school in one research subject.

The principle of conversation is used to arrange so that the conversation can run smoothly. In a conversation someone is required to master the rules of conversation so that the conversation can run smoothly and well. The principle used in conversation is the principle of cooperation and the principle of courtesy. However, in this study only focused on the politeness of the language of female students and male students with the teacher, so that it can be described gender representation in the politeness of the language used.

Representation is described as an act that presents or represents something either a person, event or object through something other than himself, usually in the form of symbols or signs (pictures, sounds, etc.) to re-display something that is felt in physical form. Gender is a major factor causing language diversity. Malmkjaer explains that gender studies that are bound by linguistics often focus on the difference between the utterances used by women and men. Survey conducted by Coates on various studies on the gender influence of speakers on linguistic variation shows that there are speeches that are exclusively preferred by women and other speeches that are exclusively preferred by men [8].

\section{METHOD}

This study uses a qualitative approach, a qualitative approach emphasizing narrative development or textual description of the phenomenon under study [2]. In this study, researchers made a description of speech events, the degree of politeness and gender representation of students in communication. The method used in this research is descriptive qualitative. Data collection techniques used through observation, recording, and card record [9]. Determination of compliance and deviation from the principle of language courtesy is based on indicators of language courtesy derived from Leech's theory. Data analysis techniques in this study were transcription of data from recordings; identifying, classifying, and clarifying data; copy to data card; analyzing data cards; and draw conclusions.

\section{A. Research Result}

Based on the findings of the data obtained in the study, found compliance and deviations of the politeness of language principles. Compliance with the principle of politeness in female students is found in (1) maxim of generosity, (2) maxim of acceptance, (3) maxim of humility, (4) maxim of agreement while deviation is contained in maxim (1) humility and (2) maxim of equality. The fall of male students is in (1) maxim of wisdom, (2) maxim of acceptance, (3) maxim of humility (4) maxim of sympathy. While deviations are in (1) maxim of wisdom, (2) maxim of generosity, (3) maxim of acceptance, (maxim of agreement, and (5) maxim of sympathy).

The fall and deviations carried out by the female students and male students are not evenly distributed, there are some maxims that are too prominent in the observance and there are some maxims that also occur irregularities but not many. Even in one type of maxim there are observations and deviations made by students. The following will describe the fallout and deviation of politeness between students and teachers based on percentage.

TABLE 1. SUBMISSION AND DEVIATION OF THE PRINCIPLE OF POLITENESS OF FEMALE STUDENTS TOWARDS FEMALE TEACHERS

\begin{tabular}{|l|c|c|}
\hline \multicolumn{1}{|c|}{ Maxsim } & Complience & Deviation \\
\hline Generosity & $3 \%$ & \\
\hline Acceptance & $9 \%$ & \\
\hline Humble & $12 \%$ & $3 \%$ \\
\hline Agreement & $9 \%$ & $3 \%$ \\
\hline
\end{tabular}

TABLE 2. COMPLIANCE AND DEVIATIONS OF THE PRINCIPLE OF POLITENESS OF FEMALE STUDENTS TOWARDS MALE TEACHERS

\begin{tabular}{|l|c|c|}
\hline \multicolumn{1}{|c|}{ Maxsim } & Complience & Deviation \\
\hline Acceptance & $3 \%$ & \\
\hline Humble & $3 \%$ & $3 \%$ \\
\hline Sympathy & $3 \%$ & \\
\hline Agreement & & $3 \%$ \\
\hline
\end{tabular}

TABLE 3. SUBMISSION AND DEVIATION OF THE PRINCIPLE OF POLITENESS OF MALE STUDENTS TOWARDS FEMALE TEACHERS

\begin{tabular}{|l|c|c|}
\hline \multicolumn{1}{|c|}{ Maxsim } & Compience & Deviation \\
\hline Wisdom & $9 \%$ & $3 \%$ \\
\hline Generosity & & $3 \%$ \\
\hline Acceptance & $3 \%$ & \\
\hline Humble & $3 \%$ & \\
\hline Symphaty & $9 \%$ & \\
\hline
\end{tabular}

TABLE 4. COMPLIANCE AND DEVIATIONS OF THE PRINCIPLE OF POLITENESS OF MALE STUDENTS TOWARDS MALE TEACHERS

\begin{tabular}{|l|c|c|}
\hline \multicolumn{1}{|c|}{ Maxsim } & Complience & Deviation \\
\hline Humble & $3 \%$ & \\
\hline Acceptance & & $3 \%$ \\
\hline Agreement & $3 \%$ & $3 \%$ \\
\hline Symphaty & $3 \%$ & $3 \%$ \\
\hline
\end{tabular}


The observance in this study was marked by the speech of students who responded well when the teacher asked. In addition, another form of maximizing wisdom is that students raise their hands if they want to express their opinions or when students make commissive speeches with the teacher. The submission of the maxim of humility in this study was marked by students' expressions of the teacher using the word "thank you" when given the opportunity to express an opinion, when the teacher gave advice, and when the teacher closed the learning meeting. The fall of the maxim of humility is marked by the speech of students who honestly convey the deficiencies that exist in him. In a maxim of humility, the speaker must praise himself as little as possible and criticize himself as much as possible. Chaer says that if we want to speak politely then as speakers, we have to be humble with our opponents. Compliance with the maxim of agreement is indicated by the speech of the student who received and agreed on an explanation or answer from the teacher [1].

Deviations in this study are marked by student speech that does not maximize profits for the speech partner, the teacher. Students as speech participants should be able to use strategies in interacting, namely speaking clearly, being polite, and always paying attention to the values of language courtesy support. Another form of deviation is contained in the maxim of wisdom which is marked by the speech of students "no ma'am, no" when asked about repeating the explanation of teaching material, of course this is a distorted attitude because students do not accept the offer given by the teacher. Other deviations are in the maxim of generosity, students as speech participants maximize their own benefits by saying "Sapri, Ma'am!", This deviation of the maxim of generosity because students shout to ask the teacher to appoint other students to answer questions. Deviations to the maxim of humility are marked by the responses of students who are not polite "Aaahhh ..." when the teacher will repeat the explanation of teaching material and other deviations are students do not say thank you to the teacher as a speech partner when given advice, instead the student only answers " Oh, I see". Deviations from the maxim of the agreement are indicated by the words "I disagree", in the speech it appears that the speaker cannot establish an agreement with his classmates.

\section{CONCLUSION}

Based on the findings and discussion of research on the principle of politeness in students' language towards teachers in the interaction of learning Indonesian in Samarinda City High School and Vocational School, it can be concluded that the principle of politeness in language of female students towards female teachers and male teachers in Indonesian language learning interactions are equally displays the compliance and deviation of the principle of politeness in language. Female students more often adhere to the principle of politeness in language to female teachers than to male teachers and more often do deviations to male teachers than to female teachers. The number of compliance with the language politeness principle done by female students to female teachers is greater than the deviation. Meanwhile, the principle of politeness in language of male students towards female teachers and male teachers in Indonesian language learning interactions both display the obedience and deviations of the principle of language politeness. Male students more often obey the principle of politeness in language to female teachers compared to male teachers and more often do deviations to male teachers than to female teachers. However, the amount of compliance with the principle of politeness in language practiced by male students towards male teachers is greater than deviation.

The principle of politeness in language based on gender in the interaction of Indonesian language learning in Samarinda City High School and Vocational High School shows compliance and deviation. Female students follow the principle of politeness in language to female teachers. Male students do more deviations to male teachers.

\section{REFERENCES}

[1] Abdul Chaer dan Leonie Agustina. Sosiolinguistik. Jakarta: Rineka Cipta, 2003

[2] Aan Komariah, Djam'an Satori. Metode Penelitian Kualitatif. Bandung: Alfabeta, 2011

[3] Chaer Abdul dan Leonie Agustina. Sosiolinguistik Perkenalan Awal. Jakarta: Rineka Cipta, 1995

[4] DWIPAYANA, I. K. A., Sudiana, I. N., \& Sutama, I. M. Kesantunan Tuturan dalam Pilihan Kode Bahasa Siswa di Komunitas SMAN 1 Ubud Ditinjau dari Perspektif Gender: Sebuah Kajian Sosiopragmatik. Jurnal Pendidikan dan Pembelajaran Bahasa Indonesia, 3 (1), 2014

[5] Febriadina, Z. F., Sumarwati, S., \& Sumarlam, S. MALE AND FEMALE STUDENTS'POLITENESS IN SRAGEN, CENTRAL JAVA. Humanus, 17(1), 2018 pp. 73-83.

[6] Gieryn, Thomas. East Lansing: Philosophy of Science Association, 1995

[7] Kuntjara, esther. Gender, Bahasa, dan Kekuasaan. Jakarta: PT BPK Gunung Mulia, 2003

[8] Leech, Geoffrey. Prinsip-prinsip Pragmatik. Jakarta : Penerbit Universitas Indonesia (UI-Press), 1993

[9] Malmkjær, K. The linguistics encyclopedia 2nd edition. Routledge, 2002

[10]Sugiyono. Metode Penelitian Kuantitatif, Kualitatif dan R\&D.. Bandung: Penerbit Alfabeta, 2014 